\author{
Ольга Власенко, \\ кандидат педагогічних наук, \\ доцент кафедри педагогіки, \\ професійної освіти та управління освітніми закладами \\ Житомирського державного університету імені Івана Франка \\ ORCID: 0000-0001-7258-2108 \\ wlasolia@gmail.com
}

\title{
АНАЛІЗ ВПЛИВУ РЕФОРМ ГРОМАДЯНСЬКОЇ ОСВІТИ НА ЗМІСТ ОСВІТИ СТАРШОЇ ШКОЛИ
}

У статті проаналізовано інтеграцію громадянської освіти України у світовий освітній простір, щуо вимагає детального вивчення сочіальної взаємодії різних краӥн, накопиченого досвіду організачії громадянського виховання, формування громадянських иінностей молоді. Автор зауважує на необхідності пошуку шляхів і способів використання досвіду зарубіжних країн у вітчизняній системі освіти. Особливо важливим, на думку автора, є вивчення й узагальнення досвіду реформування громадянської освіти в Європі, де зростає увага до демократичної освіти поряд з вихованням громадянина кожної держави.

Ключові слова: громадянське суспільство, громадянськість, громадянська освіта, громадянські иінності, учні старших класів, навчальний заклад

\section{Wtasenko Olha. Analiza wpływu reform edukacji obywatelskiej na zawartość szkolnictwa}

Artykuł analizuje wpływ integracji ukraińskiej edukacji obywatelskiej na światowa przestrzeń edukacyjna, co wymaga szczegółowego badania interakcji społecznych różnych krajów, zgromadzonego doświadczenia w organizacji edukacji obywatelskiej oraz ksztattowania wartości obywatelskich młodych ludzi. Autor zwraca uwagę na potrzebę poszukiwania metod $i$ sposobów wykorzystania doświadczeń innych krajów w krajowym systemie edukacji. Zdaniem autora szczególne znaczenie ma badanie i uogólnienie doświadczeń zwiąanych z reforma edukacji obywatelskiej $w$ Polsce, $w$ której uwaga rzadu na edukację demokratyczna rośnie wraz z wychowaniem obywatela.

Stowa kluczowe: spoleczeństwo obywatelskie, obywatelstwo, edukacja obywatelska, wartości obywatelskie, uczeniowie wyższej klasy, instytucja edukacyjna

\section{Vlasenko Olha. The analysis of the impact of citizenship reforms on high school education}

The article analyzes the impact of integration of Ukrainian citizenship education into the educational space, which requires a detailed study of social interaction of different countries, the accumulated experience of organizing citizenship education, and the formation of citizenship values of young people. The author points to the need to find ways how to use the experience of foreign countries in the native education system. It is important, according to the author, to study the experience of reforming citizenship education in Europe, where the government's attention to citizenship education is increasing nowadays.

Among the factors that influence the result of citizenship education there are: the attitude of the Ukrainian population to the authorities and political parties, corruption, numerous violations of laws and impunity, undemocratic media practices, pessimism of the population, etc., but these factors should not affect the expediency and necessity of citizenship education in educational institutions. The author notices that citizenship education should help to strengthen Ukrainian civic society. Among the disadvantages of secondary education, which negatively affect the formation of a young citizen, the author points out the lack of state regulation of the processes of citizenship education and controversial scientific positions on the history of the country, language, cultural 
processes in society, ignoring the principles of systematic and continuity in citizenship education, duplication of content lines, etc. The article clarifies that the problem of qualitative formation of high school students' system of civic values is determined by the insufficient level of interaction between educational process and citizenship education; it is determined that achievement of the optimal ratio of theoretical and practical citizenship preparation of high school students is possible on the basis of a mutually beneficial combination of the process of forming high school students' system of civic values and teaching subjects of the humanitarian cycle.

Key words: civil society, citizenship, civic education, civic values, high school students, educational institution

Постановка проблеми в загальному вигляді та ії̈ зв'язок із важливими науковими й практичними завданнями. Актуальність дослідження поняття «громадянське суспільство» зі сторони його впливу на формування громадянських цінностей молоді зумовлена процесами консолідації демократії, загрози безпеці країни, становлення волонтерства та неурядових організацій, розвитку реформ європейської інтеграції, а також радикалізації громадських протестів, насильства щодо різних груп населення, маніпулювання громадською активністю та демократією участі, появою псевдогромадянської активності та ін. Сьогодні громадянське суспільство, будучи неоднорідним і складаючись з різних груп, повинно стати найсприятливішим середовищем для реалізації прав й свобод громадян суспільства, ідей рівності та справедливості, толерантності та гідності, що, по суті, $\epsilon$ цінностями, які за певних умов сприймає свідомість кожного індивіда, змінюючи норми поведінки, систему цінностей та орієнтацій [4; 6].

Серед численних трактувань громадянського суспільства важливою для нас $є$ дефініція: «громадянське суспільство - це система суспільних відносин, яка орієнтується на загальні та приватні інтереси, гарантує безпеку суспільства в цілому та окремих громадян, має змогу контролювати державу, а його громадяни можуть реалізовувати свої права й обов'язки на основі соціальної активності» [5; 8]. Звідси, категорія «громадянськість» передбачає наділення громадян відповідними правами й обов'язками та відображає соціальний статус особистості як агента публічної діяльності.

Досліджуючи категорію «громадянське суспільство», серед основних характеристик виділяємо: орієнтацію громадян на суспільні потреби та суспільно корисні справи, небайдужість до соціальних проблем; свободу та рівність громадян, які прагнуть об'єднатися 3 метою вирішення різноманітних соціальних цілей; самоорганізацію, самоврядування та громадянські цінності; самодостатність, самовідтворення, адаптацію до зовнішнього середовища, в ролі якого виступає культура, економіка, правові норми, діючі в конкретному політичному режимі.

Громадянське суспільство передбачає формування єдиної самоорганізованої, самокерованої спільноти людей, яка буде забезпечувати рівність прав, свобод й обов'язків громадян, суспільства та держави. Тому важливим $є$ створення простору для діалогу, розробки механізмів вирішення конфліктів, які сприятимуть гармонізації суспільних відносин та стабільному розвитку громадянського суспільства. Шлях до розвитку громадянського суспільства неможливо уявити без цінностей, які лежать в основі поведінки громадян та формування їх громадянської ідентичності. Звідси виникає необхідність цілеспрямованої та узгодженої діяльності закладів освіти та громадських організацій, завданням яких $є$ не тільки адаптація молоді до життя в суспільстві, але й орієнтація майбутніх випускників закладів середньої освіти на громадянські цінності, ідеали та формування їх громадянської активності.

Аналіз основних досліджень і публікацій із зазначеної проблеми. Теорії цінностей розробляли зарубіжні вчені (Л. Вітгенштейн, В. Віндельбанд, М. Гартман, Дж. Дьюї, Р. Інгарден, А. Маслоу, Ф. Ніцше, Р. Перрі, Г. Ріккерт, М. Хайдеггер, М. Шелер та ін.) та вітчизняні науковці (А. Абульханова-Славська, Б. Ананьєв, І.Бех, С. Гончаренко, А. Гуревич, А. Здравомислов, Г. Смельяненко, М. Каган, А. Кирьякова, В. Кремень, 
М. Козловець, М. Лоський, О. Леонтьєв, В. Лях, В. Рибалка, Н. Нікандров, В. Пазенок, О. Соболь, В. Тугарінов, В. Чалий, Л. Чупрій, С. Шевченко, Д. Узнадзе та інші), які в умовах трансформації суспільства зверталися до проблем націєутворення та збереження національної ідентичності в умовах внутрішніх й зовнішніх загроз, наголошуючи на важливості ціннісних пріоритетів у добу глобалізму.

Окреслення невирішених питань, порушених у статті. Починаючи з 1991 року в Україні поступово формується державна стратегія щодо реформування системи освіти та виховання громадянина України. Зміст громадянської освіти й виховання складають цінності свободи, справедливості, рівності можливостей, солідарності, міжкультурного взаєморозуміння, захисту довкілля, здорового способу життя [9], а також освіти, безпеки, інноваційного мислення, толерантності, солідаризму, почуття власної гідності тощо [11; 12]. Під час навчання в школі (на другому етапі соціалізації) відбувається формування системи цінностей школяра, адже дитина повинна отримати знання, уміння й навички, необхідні для життя в громадянському суспільстві. Тому саме заклад середньої освіти виступає гарантом реалізації когнітивної складової громадянської освіти й виховання - системні знання про громадянське суспільство, його інститути, закони, що визначають взаємостосунки людей, особливості суспільних процесів, про права й свободи, цінності й якості та про відповідальність і обов'язки людини перед державою й навпаки.

Метою статті $є$ аналіз впливу реформ громадянської освіти на зміст освіти старшої школи.

Виклад основного матеріалу 3 обгрунтуванням отриманих наукових результатів. Сьогодні освітній процес у середніх закладах України та зарубіжних країн переживає часи суттєвих трансформацій, оскільки потреби сталого розвитку світу й кожної країни зокрема зумовлюють необхідність створення гнучкої системи громадянського суспільства, у процесі функціонування якої відповідальність переходить від держави до громадянського суспільства, а модернізаційні процеси відбуваються за широкої участі громадськості.

Українське суспільство ставить завдання перед сучасною українською школою та громадянськими інститутами забезпечити виховання свідомого громадянина України, із сформованою системою громадянських цінностей, громадянським світоглядом, активною громадянською позицією, спрямованою на саморозвиток та розвиток демократичного громадянського суспільства в країні. Держава повинна забезпечити координацію виховних зусиль громадянських інститутів суспільства, створити умови для громадської діяльності на користь суспільства відповідно до соціальних норм, законів та цінностей. Тому першочерговий вплив на будь-які трансформаційні процеси у суспільстві, окрім глобальних та регіональних тенденцій, здійснюють стратегії розвитку держави, які моделюють процеси підготовки молоді до життя й активного виконання громадянських ролей в суспільстві та ставлять за мету забезпечення умов для формування громадянина на рівні, достатньому для ефективного використання своїх прав, обов'язків та громадянської діяльності.

Систематизуючи чинники, які впливають на реалізацію системної й наскрізної реалізації принципів громадянської освіти, виділяємо нормативно-правову базу, яка визначає стратегічну мету, завдання, етапи формування громадянських цінностей молоді тощо. Відповідно до особливостей компетентнісного підходу випускники освітніх закладів мають оволодіти ключовими компетентностями, серед яких бачимо базові громадянські компетенції, необхідні для ефективної реалізації громадянських прав. Важливим є не тільки наскрізне формування громадянських цінностей в освітньому процесі нової української школи, але й розробка механізмів учнівського самоврядування.

Держава відповідає за забезпечення орієнтації державотворчих процесів на засадах гуманізму, демократії та соціальної справедливості, соціального добробуту, свободи, толерантності, відповідальності, здорового способу життя, готовності до змін, що створить для громадян України рівні стартові можливості власного розвитку, досягнення соціально значущих цілей та вплине на самовизначення та самоствердження особистості та формування іï громадянської позиції (система ціннісних і соціальних орієнтацій). 
У кінці XX та на початку XXI століття було розроблено низку концепцій - Концепція національної системи виховання (1996); Концепція національно-патріотичного виховання (2009); Концепція Загальнодержавної цільової програми патріотичного виховання громадян на 2013-2017 рр.; Концепція громадянської освіти та виховання в Україні (2012), - які тією чи іншою мірою не були повністю реалізовані через зміну траєкторій розвитку держави й системи освіти.

Зокрема в Концепції національно-патріотичного виховання в основу системи національнопатріотичного виховання покладено ідею розвитку української державності як консолідуючого чинника розвитку українського суспільства й нації загалом. Мета Концепції передбачає створення засад для системної діяльності органів державної влади й громадськості щодо виховання молодої людини-патріота України, готового виявляти національну гідність, відстоювати свої громадянські права та виконувати обов'язки, сприяти громадянському миру в суспільстві, бути конкурентоспроможним, самореалізованим в соціумі як громадянин, сім'янин та професіонал. Концепція орієнтує на виховання правової культури, поваги до Конституції України, законів України, державної символіки, історичних святинь; формування цінностей українського патріота (патріотизму, національної свідомості, любові до українського народу, його історії, Української Держави, рідної землі, родини, гордості за історію українського народу; ставлення до національної пам'яті, формування психологічної та фізичної готовності молоді до виконання громадянського та конституційного обов'язку щодо відстоювання національних інтересів та незалежності держави, виховання поваги до батьків, людей похилого віку, працелюбності, прагнення до свободи, любові до природи та мистецтва, поваги до батьків та родини; розвитку громадянської активності, психічного та духовного здоров'я; виховання здатності протидіяти проявам аморальності, правопорушень, бездуховності, антигромадської діяльності тощо). Зауважимо, що змістовими характеристиками громадянського виховання $є$ передусім орієнтація на розвиток громадянськості особистості та ігнорування включення національної самосвідомості, формування культури міжетнічних відносин та громадянської відповідальності тощо. Такий підхід ми пояснюємо своєрідністю процесу громадянського виховання молоді в Україні, зумовленого історичними та соціальними обставинами, відсутністю відповідної правової та юридичної бази, орієнтації переважно на моральноетичні імперативи як основні критерії ефективності громадянського виховання.

На сьогодні правові основи громадянської освіти в Україні закладені в Конституції України, Законі України «Про освіту» (2017), Концепції національно-патріотичного виховання дітей та молоді (2015), Національній стратегії сприяння розвитку громадянського суспільства в Україні на 2016-2020 роки (2016), Стратегії національно-патріотичного виховання дітей та молоді на 2016-2020 роки (2015), Національній стратегії у сфері прав людини (2015), Указі Президента України «Про пріоритетні заходи щодо сприяння зміцненню національної єдності та консолідації українського суспільства, підтримки ініціатив громадськості у цій сфері» (2016), Концепції розвитку громадянської освіти в Україні (2018), які пропонують конкретні кроки в процесі становлення та розвитку громадянської освіти в Україні.

Зокрема Концепція національно-патріотичного виховання дітей та молоді (2015) передбачає системну діяльність органів державної влади, громадських організацій, сім’ї, освітніх установ, інших соціальних інститутів з метою формування в молоді ціннісного ставлення особистості до українського народу, Батьківщини, держави та нації, патріотичної свідомості, почуття вірності, любові до Батьківщини, турботи про народ, готовності до виконання громадянського обов'язку, захисту національних інтересів, цілісності, незалежності України тощо. Зі свого боку, «Стратегія національно-патріотичного виховання дітей та молоді на 2016-2020 роки» звертає увагу на роль української мови як національної цінності; організації науково-дослідної та методичної роботи в царині національнопатріотичного виховання, вивченні технологій національно-патріотичного виховання, 
упровадження у зміст навчальних дисциплін духовно-морального спрямування як основи формування особистості та підгрунтя для національно-патріотичного виховання, формування єдиних стандартів діяльності в царині національно-патріотичного виховання та iн. Необхідними умовами реалізації Стратегії є координація діяльності центральних і місцевих органів виконавчої влади у сфері національно-патріотичного виховання; здійснення заходів 3 активізації національно-патріотичного виховання дітей та молоді на всіх рівнях такої діяльності у тісній взаємодії між державою та інститутами громадянського суспільства на принципах взаємозацікавленого співробітництва; підвищення рівня організації, покращення функціонування як окремих елементів системи національно-патріотичного виховання, так $\mathrm{i}$ всієї системи загалом; створення механізму підтримки об'єднань, центрів, клубів, діяльність яких пов'язана 3 національно-патріотичним вихованням дітей та молоді; розроблення системи заохочення громадських об'єднань та активістів за плідну діяльність у сфері національно-патріотичного виховання дітей і молоді. Стратегія, на жаль, не враховує теорію та практику європейського досвіду громадянської освіти, крім того, відсутні громадянські цінності, які, фактично, замінені військово-патріотичними якостями громадянина-патріота.

Важливим кроком у правовому забезпеченні громадянської освіти стало прийняття нового Закону України «Про освіту» (2017), який зазначає, що держава створює умови для здобуття громадянської освіти, спрямованої на формування компетентностей, пов'язаних 3 реалізацією людиною своїх прав і обов'язків як громадянина суспільства та усвідомлення цінностей громадянського суспільства, верховенства прав і свобод людини та громадянина. Мета повної загальної середньої освіти в документі спрямована на всебічний розвиток, виховання й соціалізацію особистості, готової до життя в громадянському суспільстві, до самовдосконалення, навчання впродовж життя, свідомого життєвого вибору, самореалізації, відповідальності, трудової діяльності та громадянської активності.

Концепція розвитку громадянської освіти в Україні (2018), продовжуючи ідеї попередніх законопроектів та концепцій, орієнтує на необхідності створення умов для формування громадянських компетентностей людини на всіх рівнях освіти та в усіх ії складниках. Освітній процес повинен орієнтуватися на цінності українського суспільства - національну самосвідомість, ідентичність, самобутність, гідність, соборність, свободу, чесність, справедливість, турботу, повагу до себе та інших людей, повагу до рідної мови та культури, патріотизм, відповідальність тощо. Крім того, у Концепції виділено цінності активної життєвої позиції, особистої ефективності, істини, правдивості та критичного мислення, взаємоповаги, відкритого спілкування та ефективної співпраці, прав людини та спільного захисту цих прав. Усі вищезгадані цінності можуть бути реалізовані через «навчання через участь» (залучення учасників освітнього процесу до діяльності та співуправління), через наскрізний підхід (реалізація ідей громадянської освіти через усі навчальні дисципліни на всіх рівнях та в усіх видах освіти), через поступальний підхід (громадянська компетентність може формуватися лише в синтезі 3 іншими ключовими компететностями). На жаль, Концепція орієнтується переважно на мету, завдання та напрями патріотичного виховання, випускаючі з поля зору проблеми формування громадянських цінностей молодої людини, іï підготовку до подальшого життя у громадянському суспільсті, захисту своїх демократичних прав, демократії й права у суспільстві та виконання обов'язків громадянина.

В Указі Президента України «Про Стратегію національно-патріотичного виховання» (2019) визначається мета національно-патріотичного виховання - формування активної громадянської позиції, утвердження національної ідентичності громадян на основі духовних цінностей українського народу, національної самобутності; формування та впровадження єдиних стандартів щодо процесів, суб'єктів, їх компетенції та повноважень, якості діяльності у сфері національно-патріотичного виховання. Досягнення мети здійснюватиметься за такими основними напрямами: удосконалення нормативно-правової бази стосовно національно-патріотичного виховання; підвищення ролі української мови як національної цінності та невід'ємного елемента національно-патріотичного виховання, здійснення заходів 
3 iі популяризації; забезпечення підтримки українськомовних дитячих i молодіжних друкованих видань, спрямованих на виховання молодого покоління в дусі патріотизму, поваги до історичного минулого та духовної й культурної спадщини, популяризацію читання, поширення українськомовного культурного продукту; розробку та впровадження сучасних виховних систем, технологій i методик у царині національно-патріотичного виховання, узагальнення та поширення кращого досвіду в ній тощо. I хоча нова Стратегія враховує виклики, пов'язані з формуванням активного та відповідального громадянина 3 високим почуттям власної гідності, стійкою громадянською позицією, готовністю до виконання громадянських обов'язків, проте згадані проблеми все ж ще не вирішені на практиці у закладах шкільної освіти.

Громадянське суспільство в Україні, незважаючи на набуття незалежності ще в 1991 році, перебуває на початковому етапі розвитку, оскільки постало перед проблемою формування нової ідеології, побудованої на власних цінностях та українських традиціях. Швидкість руху українського суспільства в напрямку розвитку демократії та створення стандартів громадянського суспільства залежить від рівня сформованості громадянської свідомості українського населення, розвитку громадянської культури та наявної системи громадянських цінностей. Сучасна демократія вимагає від молодої людини не лише політичної активності, а й усвідомлення нею власної ролі в житті громадянського суспільства, а також дій відповідно до власних переконань та поглядів. Протягом останніх років державні установи та громадські організації долучилися до розв'язку проблем громадянської освіти в Україні.

Зважаючи на гостру потребу громадянської освіти підростаючого покоління, Рада Європи в 1999 році прийняла «Декларацію та програму освіти для демократичного громадянства, заснованого на правах і обов'язках громадян», яка викликала хвилю демократичних змін у суспільному розвитку європейський країн, реформ громадянської освіти молоді та поширення активної роботи щодо створення та розвитку системи громадянської освіти й виховання в Україні.

Українські науковці, учителі-практики та громадські організації виступили ініціаторами низки досліджень спрямованих на формування громадянського суспільства в Україні - від розробки державних документів з громадянської освіти до імплементації проектів 3 метою зміцнення соціальної стабільності та національної безпеки, розвитку громадянсько орієнтованого середовища. Зупинимося детальніше на деяких з них.

Проект «Громадянська освіта - Украӥна» ставив за мету упровадження громадянської освіти як обов'язкового предмету в українські заклади середньої освіти, передбачав розробку державної навчальної програми, технологій підготовки вчителів, створення конкретних форм, методів та засобів необхідних сучасному вчителю, класному керівнику для використання в освітньому процесі школи. Зі свого боку, результатом канадськоукраїнського проекту «Розбудова демократії» стало створення пілотних навчальних програм, підручника та методичних рекомендацій для загальноосвітньої та вищої школи 3 курсу «Громадянська освіта: основи демократії». Рада міжнародних досліджень та обмінів (IREX) реалізовувала проект «Впровадження інноваційних технологій у громадянську освіту», який передбачав розробку конкретних форм, методів і засобів громадянської освіти молоді та формування їх активної громадянської позиції. Зауважимо, що спільною для вищезазначених міжнародних проектів є мета - створення умов для виховання громадянина із сформованою системою громадянських ідеалів.

Не будемо оминати увагою й участь різних недержавних організацій у громадянській освіті молоді України, які стали ініціаторами створення освітніх платформ 3 надання методичної допомоги з громадянської освіти поза системою формальної освіти. I тут варто згадати цикл безкоштовних онлайн-курсів 3 громадянської освіти на Prometheus, серед яких знаходимо «Економіка для всіх» (мета - сформувати економічний образ мислення та створити ситуації економічного успіху), «Урбаністика: сучасне місто» (мета - навчити 
молодь створювати комфортний простір у власному місті), «Боротьба 3 корупцією» (мета сформувати знання про способи проведення антикорупційних розслідувань, попереджання корупції), «Основи державної політики» (мета - сформувати знання про процеси державної політики, уміння та навички активного впливу на них) та ін.

Проект «Розвиток громадянських компетентностей в Украӥні» (DOCCU -Development of citizenship competences in Ukraine) забезпечує поширення знань про громадянську освіту в Україні через систему підготовки вчителів та громадянських діячів; ініціює створення громадянського середовища, у якому пріоритетами є громадянські цінності, закон, рівність, толерантність, повага тощо. У межах проекту створено платформу «Живемо в демократії», яка містить фрагменти уроків про демократію, громадську активність та права людини в українському суспільстві.

Проект «Громадянська освіта та електронна демократія в навчальних закладах» було спрямовано на розробку інструментів використання сучасних інформаційно-комунікаційних технологій та формування у громадян України ключових компетентностей XXI століття, передовсім громадянської. Організатори програми «Демократична школа» працювали над шляхами демократизації освітнього закладу в умовах автономії та децентралізації, зокрема через інтеграцію громадянської освіти у нові навчальні програми, створення дидактичних матеріалів для вчителів України, забезпечення якості освіти тощо.

Дослідження низки громадських організацій України продовжили діяльність зарубіжних ініціаторів у створенні громадянського суспільства.

Благодійна організація «Вчителі за демократію та партнерство» виступила організатором розробки програми громадянської освіти орієнтованої не тільки на формування знань з основ демократії, захисту прав і свобод людини, системи права i законодавства в Україні, але й на розвиток громадянських компетенцій, критичного мислення тощо. Крім того, організація виступила за підтримку учнівських соціальних проектів та впровадження нових технологій в освітне середовище навчальних закладів України для виховання активних громадян, формування ефективного самоврядування, саморозвитку вчителів, викладачів, тренерів, керівників освітніх закладів до запровадження інтерактивних технологій в освітній процес. Але на сьогодні громадська організація переважно орієнтується на особистісний розвиток молоді та їі соціалізацію (формування власної позиції, світогляду) через проведення дебатів та дискусійних клубів, формування директора-лідера та розробку форм й методів екологічного виховання молоді.

Українська Академія лідерства була створена за підтримки зарубіжних та українських організацій, політиків та громадських діячів 3 метою підготовки лідерів та формування соціального лідерства в країні. Українська академія лідерства працює в декількох напрямках - саморозвитку, командності, інтелектуального занурення, волонтерства, інтеграції в Україну та світ. Тому зміст освіти академії вражає своєю багатогранністю: від логіки, фінансового менеджменту, мистецтва, спорту та праці до української та світової філософії, історії та літератури, національної безпеки, психології тощо. Освітнє середовище академії орієнтується на формування умінь роботи в команді однодумців, формування почуттів індивідуальної та взаємної відповідальності за умови взаємної підтримки та конструктивної критики.

Всеукраїнська асочуащія викладачів історії, громадянознавства та суспільних дисциплін «Нова Доба», за підтримки Європейської комісії та інших організацій, об'єднала зусилля науковців, керівників освітніх закладів та учителів з метою створення єдиної бази форм, методів та засобів історичної та громадянської освіти, розробки шкільних підручників та онлайн компонентів існуючих шкільних курсів. Результатом спільної діяльності закладів вищої освіти, громадських організацій, науковців та дослідників стало привернення увагу до аксіологічної проблеми в громадянському суспільстві та запровадження інтегрованого курсу «Громадянська освіта» для учнів старших класів [3], що згодом спонукало розробку експериментальних підручників для закладів освіти («Ми - громадяни України», «Мистецтво 
жити в громаді», «Вчимося бути громадянами», «Вчимося обирати», «Живемо за правилами», «Компас» та ін.).

Серед інших програм та провайдерів громадянської освіти виділяємо Національну програму з прав людини «Розумісмо права людини», яка передбачала розвиток громадянської компетентності, формування демократичних цінностей та механізмів їх захисту й підтримки, умінь та навичок мирного вирішення конфліктів серед різних соціальних прошарків населення. Програма Британської ради «Активні громадяни», на сьогодні реалізована у десятках країнах світу, передбачає допомогу громадянському суспільству в соціальних реформах, змінах сталого розвитку шляхом підготовки молодих лідерів, залучення молодіжних організацій на засадах толерантності, справедливості, громадянськості, рівності вміння вести неконфліктний діалог.

Під час «Революції Гідності» виникла організація «Відкритий університет Майдану», яка об'єднала громадянських активістів, представників різних соціальних прошарків населення для формування активного громадянського суспільства та розвитку громадянських компетенцій молоді. Серед завдань університету виділяємо: підтримку неформальної освіти, створення умов у місцевих громадах об'єднання та співпраці (мережування), розробку проектів соціальної дії (мета - покращення соціальної ситуації та сталого розвитку локальних та глобальних громад) на основі цінностей громадянського суспільства співпраці, орієнтації на майбутнє, гідності, активності тощо. Для нас є цікавим створення школи ефективного мислення на базі «Відкритого університету Майдану», тренери якої пропонують бажаючим курси «Креативного мислення», «Критичного мислення», «Стратегічного мислення», «Інтегральної динаміки. Еволюції мислення, лідерства, економіки і політики» та ін.

Зауважимо, що вищезгадані провайдери неформальної громадянської освіти, працюючи на всеукраїнському та місцевих рівнях, часто використовують існуючі програми або розробляють власні, суперечливо поєднуючи різні підходи. Отже, підсумовуючи вищезгадане, спробуємо виділити недоліки й позитивні риси реформування громадянської освіти в українському суспільстві.

Серед позитивних моментів, на першому місці виділяємо державний підхід у політиці громадянської освіти молоді, який можна відслідкувати у низці державних документів, прийнятих в Україні. Проте, водночас, поруч 3 державним уніфікованим підходом до проблем громадянської освіти, усе ж відчувається потужний вплив недержавних експертів, громадських організацій, які, працюючи 3 міжнародними донорами та організаціями (Рада Європи, USAID, ПРООН, ЮНІСЕФ та ін.) часто або дублюють соціальні дії, або суперечливо трактують основні положення громадянської освіти, або тривають обмежений проміжок часу (лише протягом закордонного або українського фінансування), що не дозволяє досягти успіхів в контексті громадянських змін.

Аналіз державних документів з громадянської освіти ілюструє широке розуміння мети та завдань громадянської освіти в громадянському суспільстві - від формування демократичних цінностей молоді (право, закон, демократія тощо) до реалізації принципу взаємозв'язку навчання з вихованням, зокрема 3 патріотичним, по суті, орієнтуючи освітній процес лише на формування патріотизму як провідної цінності демократичного суспільства, що має суттєвий недолік, оскільки «розмиває» уявлення про громадянськість та громадянські цінності. Зазначимо, що ідея першості національно-патріотичного виховання в системі освіти України з часів проголошення незалежності спровокувала хаотичне використання освітніх інструментів, спрямованих на вирішення дилеми між національним вихованням патріотизму та громадянськими цінностями.

Сьогодні громадянська освіта не повинна перетворюватися на інструмент політичної боротьби, протистояння чи конфлікту в українському суспільстві, а, навпаки, формувати систему громадянських цінностей - любов до демократії, повагу до закону та обов'язку, законослухняності, політичної та громадянської активності, свободи, відповідальності тощо. 
По-третє, через фінансування європейськими та світовими донорами проектів та програм громадянської освіти в Україні, спостерігається нав'язування вже готових ідей громадянськості Європи, США та світу без урахування істинно українських традицій та проблем розвитку громадянського суспільства. Виховання глобальної громадянськості, демократичної громадянськості (global citizenship, democratic citizenship) у сучасних документах Ради Європи повинно відбуватися через навчання, причому особливий акцент здійснюється на проведенні тренінгів, дискусійних клубів, роботи ЗМІ, взаємозв'язку освітнього закладу 3 політичними інститутами. Зарубіжні науковці переконують, що в ситуації недостатньої ефективності громадянської освіти в закладах освіти функцію виховання громадянина суспільства повинні взяти на себе політичні партії та громадянські організації, діяльність яких, на нашу думку, усе ж буде відрізнятися упередженістю громадянської освіти.

Нам імпонує думка С. Рябова [10], який уважає, що саме освітнім закладам повинна належати основна роль у формування громадянина українського суспільства, адже тільки освіта може забезпечити цілеспрямований, систематичний процес впливу на формування громадянської компетентності, а також системи громадянських цінностей українців. Науковець виділяє недоліки середньої освіти, які негативно впливають на формування молодого громадянина, серед них - відсутність державного регулювання процесів громадянського виховання молоді та єдиної наукової позиції щодо історії країни, мови нації, культурних процесів у суспільстві, ігнорування принципів системності та наступності в громадянській освіті молоді, надмірна теоретизація навчального матеріалу, дублювання змістових ліній, брак діяльнісної складової тощо. Продовжуючи думку С. Рябова, серед чинників, які впливають на результат громадянської освіти виділимо: ставлення українського населення до влади та політичних партій, корупцію, числені порушення законів й безкарність, недемократичні практики ЗМІ, песимізм населення та ін., проте це не повинно впливати на доцільність й необхідність громадянської освіти молоді в закладах освіти [1; 7].

Ми підтримуємо думку науковців (Т. Асламова, Т. Бакка, Я. Боренько, В. Бортніков, Т. Колган, С. Куксенко та інших) у тому, що держава має зосередитися на нагальній потребі формування громадянських цінностей молоді (демократичності, толерантності, відповідальності, громадянськості тощо), забезпечити розробку інноваційних форм і методів роботи з молоддю, її активного залучення до політичних та соціальних проблем.

Висновки та перспективи подальшого дослідження проблеми. Розробка системного впливу на освітній процес у контексті ідей, положень, цінностей громадянської освіти $\epsilon$ на сьогодні нагальним завданням для вирішення провідних проблем становлення української державності - формування нації, системи громадянських цінностей, громадянської ідентичності та зміцнення громадянського суспільства. У рамках української культурної традиції природним представляється розгляд феномена процесу формування громадянських цінностей школярів як системи комплексної діяльності з формування громадянських якостей особистості, як цілісної соціальної системи, пов'язаної як з суспільством загалом, так і 3 освітнім процесом навчального закладу зокрема.

\section{Список використаних джерел та літератури}

1. Асламова Т., Бакка Т., Бортніков В. Громадянська освіта: теорія і методика навчання. Режим доступу: http://sites.znu.edu.ua/interactiv.edu.lab/Posibnyky/TTG main.pdf (дата звернення: 11.10.2019).

2. Власенко О. Аксіологічна спрямованість предметів гуманітарного циклу в контексті формування системи громадянських цінностей учнів освітнього закладу. Збірник наукових праць «Педагогічні науки». Випуск LXXXI. T.2. Херсон : Видавничий дім «Гельветика», 2018. С. 44-48.

3. Громадянська освіта як інструмент формування громадянського суспільства в Україні: проблеми та шляхи їх подолання. Актуальні проблеми громадянської освіти та виховання: український та зарубіжний досвід. Режим доступу: https://eprints.oa.edu.ua/2394/1/mater_konfer_web-1.pdf

4. Громадянське суспільство України: сучасні практики та виклики розвитку : аналіт. доповідь / Яблонський В. М., Андріученко Т. В., Бекешкіна I. Е. та ін. К., 2018. 128 с. 
5. Зырянов С. Г. Основные функции гражданского общества: теоретический аспект. Социум и власть. 2017. Т. 1.2 (64). С. 15-16.

6. Ковальчук В. Громадянське суспільство та його правові цінності в умовах демократичної трансформації: досвід України. Вісник Національного університету «Львівська політехніка». Юридичні науки. 2017. № 865. С.83-89.

7. Колган Т. В. Громадянська освіта та виховання школярів. Режим доступу: http://kolgantv.blogspot.com/2009/11/blog-post_9052.html (дата звернення: 15.10.2019).

8. Новая философская энииклопедия. В 4-х томах. Т. 1. М. : Мысль. 2010. С. 549.

9. Соннова М. Зарубіжний та вітчизняний досвід громадянського виховання. Вісн. Львів. ун-ту. Сер. пед. 2006. Вип. 21, ч. 1. С. 123-130.

10. Рябов С. Г. Політологічна теорія держави. К. 1996. 240 с.

11.Ціннісні орієнтації сучасного інформаційного суспільства: монографія / В. Пазенок, В. Лях, О. Соболь та ін.; НАН України, Ін-т філос. Київ, 2013. 406 с.

12. Щербакова Ю. Е. Цінності об’’днаної Європи: монографія. Київ, 2014. 206 с.

\section{References (translated \& transliterated)}

1. Aslamova, T., Bakka, T., Bortnikov, V. (2008). Hromadianska osvita: teoriia i metodyka navchannia [Citizenship education: theory and methodology of teaching]. Retrieved from http://sites.znu.edu.ua/interactiv.edu.lab/Posibnyky/TTG_main.pdf [in Ukrainian].

2. Vlasenko, O. (2018). Aksiolohichna spriamovanist predmetiv humanitarnoho tsyklu v konteksti formuvannia systemy hromadianskykh tsinnostei uchniv osvitnoho zakladu [Axiological orientation of humanitarian subjects in the context of forming the system of civic values of schools' students]. Zbirnyk naukovykh prats «Pedahohichni nauky». Iss.LXXXI. T.2. Kherson, 44-48 [in Ukrainian].

3. Hromadianska osvita yak instrument formuvannia hromadianskoho suspilstva v Ukraini: problemy ta shliakhy yikh podolannia [Citizenship education as a tool of forming of civil society in Ukraine: problems and ways of overcoming them]. Aktualni problemy hromadianskoi osvity ta vykhovannia: ukrainskyi ta zarubizhnyi dosvid. Retrieved from https://eprints.oa.edu.ua/2394/1/mater konfer web-1.pdf [in Ukrainian].

4. Hromadianske suspilstvo Ukrainy: suchasni praktyky ta vyklyky rozvytku: analit. dopovid (2018). [Civil society of Ukraine: current practices and challenges of development: report] / Yablonskyi V., Andriuchenko T. ta in. K., 28-54 [in Ukrainian].

5. Zy’ryanov, S. (2017). Osnovny`e funkczii grazhdanskogo obshhestva: teoreticheskij aspekt [The main functions of civil society: theoretical aspect]. Soczium $i$ vlast '. Vol.1.2(64). 15-16. [in Russian].

6. Kovalchuk, V. (2017). Hromadianske suspilstvo ta yoho pravovi tsinnosti v umovakh demokratychnoi transformatsii: dosvid Ukrainy [Civil society and its legal values in the conditions of democratic transformation: the experience of Ukraine]. Visnyk Natsionalnoho universytetu "Lvivska politekhnika". Yurydychni nauky. Iss. 865. 83-89 [in Ukrainian].

7. Kolhan, T.V. Hromadianska osvita ta vykhovannia shkoliariv [citizenship education and upbringing of students]. Retrieved from http://kolgantv.blogspot.com/2009/11/blog-post 9052.html [in Ukrainian].

8. Novaya filosofskaya e ncziklopediya (2010). [The New Philosophical Encyclopedia]. V 4-kh tomakh. T.1. M. My`sl`. 549. [in Russian].

9. Sonnova, M. (2006). Zarubizhnyi ta vitchyznianyi dosvid hromadianskoho vykhovannia [Foreign and domestic experience of citizenship education]. Visn. Lviv. un-tu. Ser. ped. Vyp.21, Iss.1. 123-130. [in Ukrainian]. 10. Riabov, S.H. (1996). Politolohichna teoriia derzhavy [Political science theory of the state]. K., 240 p. [in Ukrainian].

11. Tsinnisni oriientatsii suchasnoho informatsiinoho suspilstva (2013). [Value orientations of the modern information society]: monohrafiia / V. S. Pazenok, V.Liakh, O. Sobol ta in.; NAN Ukrainy, In-t filos. Kyiv, 406 p. [in Ukrainian].

22. Shcherbakova, Yu. (2014). Tsinnosti obiednanoi Yevropy [The values of Europe]: monohrafiia. Kyiv, 206p. [in Ukrainian].

Статтю отримано 08.11.2019 року

Прийнято до друку 10.12.2019 року 